population. With these developments there was growing interest in closed-circuit television systems of all kinds and at every level; the Cambridge Television Woek had just demonstrated the potentialities of two-way lecturing links with inter-university serninars.

This steadily developing network of communications would afford during the next ten years an opportunity to demonstrate still further the edueational uses of radio, and to mako as extensive a use of educational television as Japan and Italy were already doing. During the present school ycar the Corporation would be transmitting 63 radio programmes, reaching more than 30,000 schools each week during term time at an annual cost of $£ 522,000$. The newer service of school television now provided 15 programmes all repeated in the same week and reaching some 6,000 schools at an annual cost of $£ 844,000$, and last year a now service for technical colleges was started.
From January 1964 the adult education service would have a "Study Session" hour of its own and audiences for these programmes ranged from 50,000 to 150,000 with a steady sale of 50,000 pamphlets for each beginners' language course. New television programmes in this field had started and the Corporation had also announced its intention to devote Tuesday evening on the new channel to specifically educational purposes. Mr. Scupham discussed the specific contribution which broadcasting and tclevision can offer to educational purposes and, after referring to the new Working Party on Higher Education over which Mr. Fulton, vice-chancellor of the University of Sussex, is presiding, mentioned that in April a new major series was starting for teachers on the new mathematics and its industrial and pedagogical implications. The new services would cost some $£ 2$ million of the Corporation's licence revenue in 1964 .

\title{
SCIENCE MUSEUMS IN DEVELOPING COUNTRIES
}

$T$ HE museum devoted to science takos its place in present-day society along with the central library, the historical museum and the art gallery. The responsibilities of such a museum are two-fold, first, to present through its exhibits a picture of the current state of knowledge in the various branches of seience, in particular recent developments, and secondly, to illustrate from its beginnings the history of the subject. This latter function involves the collection of significant historical material. The present time is one of greatly increased activity in the organized preservation of the material evidence of the history of science and technology by museums and other professional bodies, and it is with this that the present note is concerned.

In Great Britain the collection of scientific material of historical importance has been a primary duty of the Science Museum at South Kensington since its foundation in 1857. Similar functions have, for example, been carried out by the Conservatoire des Arts et Métiers in Paris and by the Smithsonian Institution in Washington. The policy of the Science Museum in this respect has been. in large measure, that expressed in 1874 by the Devonshire Commission on Scientific Instruction which enjoined the preservation of material which was notable "by reason of the researches in which, or the persons by whom it was employed". The apparatus used by the investigator who made the primary experiments, his note-books and related material are unique and, properly, have pride of place in any national collection. In this context, however, science embraces technology, and technological material is not unique in the same sense. Technological advance involves development and ultimately duplication and often multiplication of some product on a massive scale.

This multiplicity of examples of significant technological developments might be expected to ensure the survival of a suffieient number to satisfy the very limited needs of museums. This has by no means always been true in the past and will in one respect at least inevitably be less true in the future for, assuming that the long-established science museums of the technologically advanced countries are fully supplied with examples covering the past hundred years, it is to be expected that countries now undergoing rapid technological development will, before long, be establishing science museums themselves and endeavouring to collect as many early examples as they can. There is, therefore, a clear duty on the part of the longer industrialized communities to preserve material for the museums which will be established in the younger territories. Great credit must be given to the museum authorities themselves for the remarkable degree of co-operation they have achieved in collecting material for sister institutions, but the problem of the storage of material and of the dissemination and exchange of information is an exceedingly difficult one. Items which already are satisfactorily represented in practically all the existing museums but which could be important exhibits in a new institution become available from time to time, and often go to the scrap heap simply because their potential value is not appreciated, or it may be impossible to store.

It ean indeed be said that an interest in old scientific and technological material is fairly widespread in Britain, and in certain branches of engineering very well developed indeed. Motor-cars, railways and steam engines might be cited as examples. Many important areas of the field are, however, only known to specialists. Enlightened in this matter as an individual or an organization may be, the fact remains that, at the present time, it is not easy to find a willing recipient for material which duplicates examples already in the possession of the major collections. In Britain the great collection of the Science Museum is supplemented by substantial science and technology sections in the Royal Scottish Museum, Edinburgh, the Glasgow Museum, the National Museum of Wales in Cardiff and the Birmingham City Museum. A number of industrial organizations and nationalized industries, for example the British Transport Commission, have private museums and small collections exist in various university departments.

A recent development which should do much to co-ordinate the resources and policies of museums in a region, and which should greatly improve the present situation, is the formation of museum area councils. An important related activity, the preservation of some of the larger monuments of the industrial era, has become a matter of concern to historians who, through the Council for British Archæology, are promoting steps to preserve engines. factories and other large remains. Important as these. developments are, they do not in themselves help to solve the urgent problem of collecting and storing material which would be invaluable in a few years' time to museums in developing countries.

Three lines of action suggest themselves: (1) Suitable press and tolevision publicity to explain the nature of the problem, and to deseribe the range of material of potential interest. (2) The establishment of a central office which would receive offers and enquiries and would endeavour to 'channel' them appropriately. (3) The allocation of suitable vacant buildings as stores and the provision of funds for the maintenance of the stores and the transport of material. 
Already museum staffs are engaged in various programmes of assistance to underdeveloped countries. If financial and organizational help were forthcoming there is no doubt about the willing co-operation which would be offered in collecting scientific and technological material for the museums which will be established in developing territories. Initiative at Government-level would appear to be an essential first step. JAMES GRET:

\section{SEARCH FOR OIL AND GAS POOLS BENEATH THE NORTH SEA}

$\mathrm{O}$ FFSHORE drilling for oil within continental shelf deposits has for some years past been established procedure in determining seaward extensions of proved land-based oil and gas fields, notably in the United States. The great advances in design, construction and adaptability of modern drilling 'barges' has made such projects economically feasible if not always commercially successful. So far as the United Kingdom is concorned, offshore drilling history was made in the autumn of 1963 by the first exploratory well put down $2 \frac{1}{2}$ miles off the coast at Lulworth Cove, Dorset, in this case using a self-elevating mobile De Long barge, in $60 \mathrm{ft}$. of water. The pioneers of this venture were the British Petroleum Company, who have also been granted permission by the Dutch Government to search for oil and gas in the Wadden Zee area off the northern Dutch coast.

Geologists in Britain, as in other West European countries bordering the North Sea, have long realized the possibilities of oil or gas pools (or both) existing in the sedimentary deposits constituting its floor, but by general consent the chances of locating commercially worthwhile supplies were not rated very high. This vista was, however, rapidly changed by the recent discovery and development of a major gasfield in the Groningen area in the Netherlands (Nature, 200, 123; 1963), the seaward extension of which is now the objective of great activity by various international oil interests. Prior to this, however, interest in the potentialities of the North Sea shelf off Britain was roused in 1961 when the British Petroleum, Esso and Shell Companies announced the start of a joint seismic survey of 30,000 square miles of the North Sea basin. Many ships carrying out such surveys, from Lowestoft to the Firth of Forth, have since been operative, under direction of the Shell Com. pany of the United Kingdom, Ltd., employing contractors. "This autumn, the experts in Bataafse Internationale Petroleum's Exploration and Production Division in The Hague should have in their hands a reasonably comprehensive picture of this stretch of the North Sea floor; it will have cost some half a million pounds to obtain but will provide the essential basis for a decision on where to continue seismic work or whether to start underwater drilling, and if so, where" (Search in the North Sea, Information Circular No. 40, Shell International Petroleum Co., Ltd., London; October, 1963). Other geophysical surveys have been in progress within a 20,000 square mile area off the coasts of Yorkshire, Lincolnshire and Norfolk, under the ægis of Pan American International Exploration Co., in association with the British Gas Council and some other American companies. The French
State concern BRP, through its British subsidiary, Coastal Oil, has been working an area of some 180 square miles within British territorial waters off the Yorkshire coast, and also carrying out seismic surveys in other parts of the North Sea.

Apart from the exploratory work off the east coast of Britain, Shell and Esso Companies (through a joint organization known as NA.M, that is, Nederlandse Aardolie Mij.), who were responsible for the gas discoveries in Holland, have been operating off the Dutch coast, both north and west; in the latter zone four offshore wells were drilled in 1961-62 at a total cost of $f 1.4$ million. In 1963 an extensive programme of seismic surveying within and beyond Dutch territorial waters was prosecuted. The net has, however, been spread much further recently, embrac. ing Scandinavian and Danish seaboards. In Norwegian waters Shell, Esso and British Petroleum group have conducted surveys; Phillips Petroleum, also the French concerns BRP and RAP have been active here. In Denmark, A. P. Møller, the shipowner, has obtained a 50-year exploration concession covering the whole country including Danish territorial waters; he, together with Gulf Oil Company (U.S A.) and Shell, are undertaking joint exploration in this region. Offshore developments in Germany are being sponsored by certain German oilproducing companies in which Pan-American oil interests are active.

Thus in the West European region of the North Sea basin the problems of North Sea oil and gas pools are well on their way to solution. According to the Shell Information Circular No. 40: "The surveys may show structures that might contain oil or gas but they may well prove to be empty; or oil may be present there but the first holes drilled may miss it. Fven if there were a show of gas or oil, it would be some considerable time before a suffieient number of exploration wells could be drilled for the companies to be able to determine whether or not they had discovered really significant reserves on Western Europe's doorstep". Oil and gas are not the only problems raised should commercial success reward these efforts of the oil companies; there may ensue interminable arguments on the question of who owns the mineral (including oil and gas) rights over the bottom of the North Sea. Some guidance on the legal aspects of this problem is provided by the Intermational Convention on offshore rights, drawn up by the Geneva Conference on the Law of the Sea in 1958; but so far, except for Denmark, none of the countries bordering the North Sea have ratified the convention and much internal legislation is likely before they do so.

H. B. MTINER

\section{POTATO RESEARCH IN BRITAIN}

ARGELY as the result of amendments to the Potato
Marketing Seheme, the Potato Marketing Board can
now increase its contribution towards research and assist
attempts to answer some of the problems facing the indus.
try to-day. To help it to do this, the Board has set up a
Research and Development Committee to advise on ways
in which research on potatoes can be encouraged and
assisted. In addition to the chairman, Mr. J. E. Rennie,
and six other members of the Board, who represent the intorests of the potato growers, the Committee consists of F. C. Bawden (director of Rothamsted Experimental Station), W. H. Cashmore (director of the National Institute of Agricultural Engineering), F. R. Horne (director of the National Institute of Agricultural Botany), Prof. Alexander Robertson (Agricultural Research Council), Prof. S. J. Watson (Edinburgh School of Agriculture) and Prof. W. T. Williams (University of Southampton). Dr. E. E. Cheesman provides the necessary liaison with 